\title{
Michel Hockx, Internet Literature in China,
}

New York, Columbia University Press, 2015, 251 pp.

\section{Shuang Xu}

Translator. Jonathan Hall

\section{(2) OpenEdition}

\section{Journals}

Electronic version

URL: http://journals.openedition.org/chinaperspectives/6944

DOI: 10.4000/chinaperspectives.6944

ISSN: 1996-4617

Publisher

Centre d'étude français sur la Chine contemporaine

\section{Printed version}

Date of publication: 1 March 2016

Number of pages: $71-72$

ISSN: 2070-3449

Electronic reference

Shuang Xu, « Michel Hockx, Internet Literature in China, », China Perspectives [Online], 2016/1 | 2016, Online since 01 March 2016, connection on 24 September 2020. URL : http://journals.openedition.org/ chinaperspectives/6944; DOI : https://doi.org/10.4000/chinaperspectives.6944 
of the power-capital institution, studying it in three successive modes: as a political economy, as a coalition of entrepreneurs, and as a social culture. The alliance between political power and capital, whose main stages of development over the period in question are swiftly outlined by the author, took place in such a manner that ruled out the normal political expectations from a numerical increase in the size of the middle class. The author develops his theoretical perspective still further by analysing the "power-capital economy" as a system distinct from both a market economy and a centrally planned one, but functioning in a perpetual oscillation between the two, thus constituting itself as a semi-autonomous economic mode. He therefore argues for the need to see the socio-economic functioning of the Chinese economy as tri-polar. The ambiguity of this system largely explains the ambiguous nature of the strategies of the "entrepreneurs" at the heart of the power-capital institution. Moreover, the nature of the alliances set up by them has prevented the possibility of any progressive maturing of a civic culture worthy of the name. The dominant culture, writes Zhaohui Hong, is that of the " 3 Cs" (Confucian, Communist, and Culture of Power and Capital). Here, too, he argues for an analysis based on a systemic analysis of these three dimensions taken as a whole in order to study the cycles of China's political culture and foresee its implications.

The second part focuses on the Have-Nots and is based on analyses of the different sectors. Its first chapter deals with China's urban population. Here the author goes beyond establishing a global link between poverty and restrictions on rights by arguing for affirmative action programmes targeting clearly identified groups, especially among the urban population. This line of analysis is extended to cover the various restrictions on rural property rights as well as on the legal and social status of migrant workers. The last chapter goes into considerable detail in order to throw light on the situation of "house churches," emphasising once again the restrictions on the exercise of the right to religious freedom. This chapter also contains a fairly strong programmatic side, urging the leaders of the clandestine Protestant churches to show more pragmatism and to make better use of the remaining space for initiatives.

The rather brief conclusion acknowledges the way in which "the powercapital institution" analysed in the first chapter of the book was perhaps the inevitable outcome of the reorganisation of the social strata and other restructurings at a time of unparalleled socio-economic transition. In this respect, the author does not argue for their demolition but rather for their integration into a legal framework with public supervision, and a progressive programme for increased democracy. China will be unable to reform itself without dissociating political power from capital, and this dissociation must be conducted within a reformed legal framework.

The main interest in this work lies in the systematic character of its analysis. This overall systemic approach is not without its risks: its nuances often get bogged down by a theoretical formula that dominates the whole without helping to shape all its developments. Moreover, the stress placed on the elites on the one hand and the disadvantaged on the other does not give due importance to developments and strategies specific to the middle class: the latter is said to have struck an implicit bargain with power in order to garner for itself some of the proceeds of growth - but the analysis hardly goes further than that. This observation should be extended through a study of the "social ruses" and cultural trends also operating within that middle class. After all, would this not be the very section of the population that is contributing to the extension of the rights conceded by the political power (albeit indirectly and only partially), reducing thereby the global "price" of the growth process and creating some of the cultural and social resources omitted from this book's analysis? Because of this omission, the pages on the "civic culture" such as it exists in present-day China are perhaps too pessimistic, although that assessment may be open to question.

In any event, this book will certainly prove to be a valuable reference work (even if only to provoke queries) for any reader concerned with testing the models that attempt to give an account of the implicit "social contract" currently in force in China today, and to assess its durability as well as its weaknesses.

I Translated by Jonathan Hall.

Benoît Vermander is a professor at the School of Philosophy at Fudan University, Shanghai (mdwei@fudan.edu.cn).

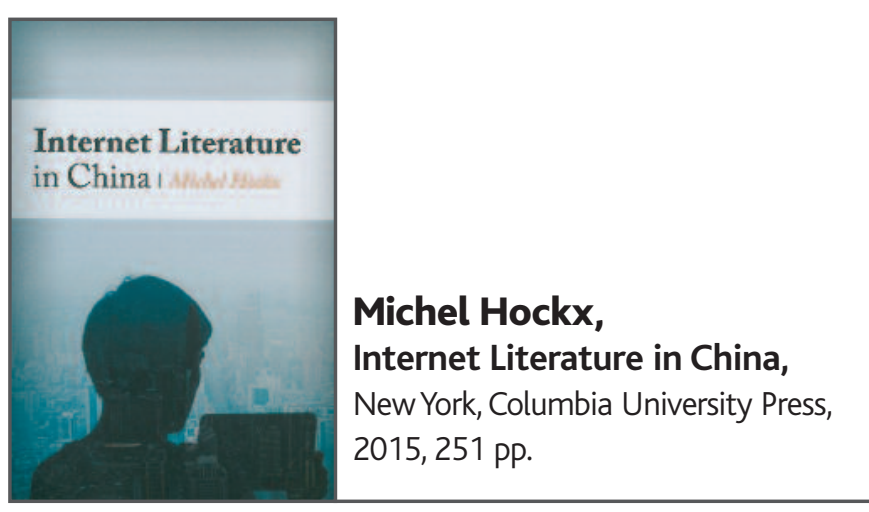

\section{SHUANG XU}

nternet Literature in China is the fruit of Michel Hockx's work over the last decade. In this volume the author examines the new literary form in the broad context of Chinese "postsocialism," which he characterises as a "condition of ideological contradiction and uncertainty" (p. 13). His observations are based on his reflections, which combine literary and social questions. He asks how Internet literature brings about innovations in Chinese printed literature, as well as in the electronic literature that is already well developed in the West. And how does its publication manage to defy the government censorship system as it transgresses its boundaries? The author sets out to probe the phenomenon of Internet literature in order to examine the process of social transformation in China, and to offer "a general overview, useful not only for specialists but also for general readers interested in present-day China and its culture" (p. x).

The work opens with an overall presentation of the development of Internet literature in China (Chapter 1). The birth of this new literature in the 1990s is compared with the profusion of literary magazines at the beginning of the twentieth century. According to Hockx, these two phenomena have some common features: literary innovation linked to new technologies, the formation of new communities around literary production, and the coexistence of differing literary tastes and divergent linguistic and cultural registers. He believes that Internet literature is in the process of establishing its own norms and values, which are not identical to those of its printed counterparts. The chapter ends with a study of the first literary website in China, "Under the Banyan Tree," which throws light on the methods of producing online publications, and on the actual practices of a literary community based on digital interactions. He also follows 
the trajectories of different online writers to bring out a new form of literary canonisation, and the potential for creating new literary genres.

The second chapter takes a closer look at literary innovation in the work of three active Internet authors. Chen Cun (b. 1954) was one of the first recognised writers in printed literature to enter the digital scene in the late 1990s. He still follows this avant-garde experimental path in his own online forum, the "Minority Vegetable Garden" (xiaozhong caiyuan 小罝菜園), where he publishes matters that are taboo in printed literature, such as "Random Notes on Sex" (xing biji 性筆記), and where he attempts to break free from the stifling conventions in fiction in favour of a more direct form of written expression. Moreover, his forum includes a selective literary circle, modelled on the tradition of Tao Yuanming (365-427). The second writer, Wen Huajian (b. 1972), is the author of the first novel in the form of a microblog (weibo xiaoshuo 微博小說), a new literary genre that later developed under the name of "micro-fiction" (wei xiaoshuo 微小說). In terms of both form and content, his writings probe the boundaries between serious and obscene literature, as well as those separating fiction, virtual reality, and the real world. The third example, Han Han (b. 1982), has revived the genre of the satirical essay (zawen 雜文) characteristic of Lu Xun's style, thanks to the social criticism in his blogs. The powerful media impact of his frontal attacks on the established publishing system has enabled a defence of authors' rights against piracy in the case of certain digital publications. He also explores the possible use of mobile phone apps in order to widen the field of independent literary publication.

The following chapter focuses on online fiction and the censorship policy aimed at moral and political offenses. Taking the Qidian 起點 website as his example, Hockx begins with a description of its general organisation. He emphasises that its economic model is closely linked to the interactions between author, reader, web administrator, and editor. He points out that creating a website involves re-interpreting certain literary ideas, such as the term wenxue 文學 (literature) or qihuan 奇幻 (fantasy). The chapter goes on to consider state control over the online fiction read by millions of readers outside the system of printed publications. Hockx broaches this issue by opting for the "obscene and pornographic" fiction that presents a threat to current legislation. His study of two websites, Feilu 飛路 and Heilan 黑籃, lays out in detail some of their strategies for bypassing censorship measures.

The final chapter studies Internet poetry from different angles: aesthetic development, moral transgression, and the re-appropriation of poetry's social function. His study of two influential websites for poetry in China, Poemlife (shi shenghuo 詩生活) and Chinapoet (Zhongguo shiwang 中國 詩網), reveals the appearance of poetic creations in the classical style. The author stresses that the hybrid combination of modern and classical styles calls for the creation of a new critical discourse to respond to this poetic innovation. Moreover, the originally "dissident" Jintian 今天 website seems to have won acceptance in China thanks to the creation of new transnational spaces. His case study of the avant-garde group xiabanshen 下半身 (lower body) returns to the question of moral transgression. The separate careers of two women poets - one having achieved canonical status (Yin Lichuan) and the other being permanently censored (Datui) - raises the question of the boundary between literariness (p. 162) and obscenity. The chapter ends with a study of the formal innovations of online poetry: the animated textual morphs (p. 168), the Chinese version of electronic poetry, the English sinographic poetry (p. 175), and the visual poetry of Dajuin Yao.
The volume includes copious endnotes classified according to chapter, a bibliography, a traditional index, and an explanation of how to use online sources. In addition, owing to the ephemeral nature of some of the documents, the reader is given access to an archive of digital references in the Zotero Group Library. The book is easily consulted and very practical to use. My only regret is the absence of a glossary and of Chinese characters for proper names.

To the best of my knowledge, Michel Hockx's book is the first Western study to provide a global introduction to online literature in China. In this respect it complements two other recently published works: Jin Feng's study of romantic novels (Romancing the Internet: Producing and Consuming Chinese Web Romance, Leyden, Brill, 2013) and Heather Inwood's work on poetry (Verse Going Viral: China's New Media Scenes, Seattle, University of Washington Press, 2014). Hockx's book is extremely informative, and it also provides the first methodological steps towards a study of Internet literature in China. In sum, this is an important contribution, not only to Chinese studies but also to the study of digital literature elsewhere in the world.

I Translated by Jonathan Hall.

I Shuang $X u$ is an associate professor at Paris Diderot University, East Asian Languages and Civilisations Department, and researcher at the Centre de recherche sur les civilisations de l'Asie orientale (UMR 8155) (shuang.xu@univ-paris-diderot.fr). 